\title{
CORPORATE GOVERNANCE AND CAPITAL ASSET PRICING MODELS
}

\author{
ALYNE C. S. GANZ ${ }^{1}$ \\ http://orcid.org/0000-0002-7192-6033 \\ JOSIANE O. SCHLOTEFELDT ${ }^{2}$ \\ (iD) https://orcid.org/0000-0002-0151-3276 \\ MOACIR M. RODRIGUES JUNIOR ${ }^{3}$ \\ (iD) https://orcid.org/0000-0003-0309-3604
}

To cite this paper: Ganz, A. C. S., Schlotefeldt, J. O., \& Rodrigues Junior, M. M. (2020). Corporate governance and capital asset pricing models. Revista de Administração Mackenzie, 21 (2), 1-27. doi:10.1590/1678-6971/eRAMF200010

Submission: Jan. 16, 2019. Acceptance: Sept. 5, 2019.

1 Universidade Federal do Paraná (UFPR), Curitiba, PR, Brazil.

2 Centro Universitário - Católica de Santa Catarina (CatólicaSC), Jaraguá do Sul, SC, Brazil.

3 Universidade Regional de Blumenau (Furb), Blumenau, SC, Brazil.

\section{(cc) BY




\section{ABSTRACT}

Purpose: This study aimed to analyze the inclusion of corporate governance in the explanation of Fama and French's $(1993,2015)$ three and fivefactor asset pricing models.

Originality/value: This research differs from other works by inserting corporate governance as an explanatory factor in the pricing model of financial assets. Thus, it is intended to contribute to the research area by trying to identify previously unexplored characteristics, as the proposed method, that helps and adds explanation to the pricing models of financial assets, thus helping investors and professionals in the financial area.

Design/methodology/approach: The research sample consists of 387 companies listed in B3, in the period between 2012 and 2016. For data analysis, panel data regressions were used according to the methodology of Fama and French studies $(1993,2015)$ through the Stata software.

Findings: The results indicate that corporate governance has a negative impact on the return of the actions of small companies with lower levels of corporate governance and that the reverse is true for large companies with high levels of governance. Other variables were also found to be impacting on stock returns, such as market value, book-to-market, profitability, and investments.

\section{KEYWORDS}

Risk. Return. Corporate governance. Novo Mercado. Capital Asset Pricing Model. 


\section{INTRODUCTION}

Stock prices, as well as changes and fluctuations in the capital markets, have always attracted the interest of researchers and investors, and have been the object of constant study (Mendonça, Klotzle, Pinto, \& Silva Montezano, 2012). Risk and return analysis in the context of asset pricing is pioneered by the Markowitz (1952) study, which started a research line about risk estimation and return on assets. Sharpe (1964), Lintner (1965) and Mossin (1966) improved the Markowitz's (1952) initial model, developing the widely known Capital Asset Pricing Model (CAPM), the central model in asset pricing theory, that replaces the variances of the original model with known indices.

CAPM has been empirically validated several times, after which, complementary models have emerged with the objective of improving the applicability and explanation of the model, including Intertemporal Capital Asset Pricing Model (ICAPM) (Merton, 1973), the D-CAPM (Estrada, 2002) and the three-factor and five-factor models (Fama \& French, 1992, 2015). Of these, the three-factor model of Fama and French (1993) stands out because it considers not only systemic market risk but also size and marketto-book effects (Costa, Mazzeu, \& Costa Jr., 2016).

Several prior studies have related stock returns to factors such as risk, volatility, and governance (Ferreira \& Laux, 2007; Nguyen, 2011; Mendonça et al., 2012; Azevedo, Santos, \& Campos, 2016). Among these, there are studies that investigate the relationship of corporate governance levels with several factors that may or may not impact it. The study about the impact of these practices on the share price and the distribution of returns is a significant issue in the area of corporate finance (Ferreira \& Laux, 2007). Several studies indicate that governance may influence stock prices (Shleifer \& Vishny, 1997; Gompers, Ishii, \& Metrick, 2003; Cremers \& Nair, 2005; Ferreira \& Laux, 2007). Considering that stock price is a measure of business performance and well worth a similar analysis, the literature investigating the influence of corporate governance on the company's performance is even more abundant (Freitas, Silva, Oliveira, Aquino Cabral, \& Santos, 2018; Bhagat \& Bolton, 2019; Ciftci, Tatoglu, Wood, Demirbag, \& Zaim, 2019).

This is why corporate governance is characterized as a set of regulations, techniques and institutions that determine how managers act to promote the best for the organization by considering the interests of the various stakeholders, particularly shareholders (Leal \& Saito, 2003; Fonseca, Silveira, \& Hiratuka, 2016). It is sometimes considered the means by which 
foreign investors can check the company's management actions (La Porta, Lopez-de-Silanes, Shleifer, \& Vishny, 1999; Bhagat \& Bolton, 2019).

Thus, corporate governance characterizes a significantly important part of the organizational context. Therefore, efforts to promote the best practices of this kind have become a constant and highly relevant concern (Fox, Gilson, \& Palia, 2016), directly impacting company value (Xu \& Wang, 1999). According to Lopes and Walker (2012), corporate governance activities lead to greater transparency of management by the company, thereby reducing the degree of information asymmetry between the parties (Silva, Azevedo, Fonsêca, \& Gomes, 2019).

On the national scene, the main activity to achieve the best corporate governance practises was the development of Brasil, Bolsa, Balcão (B3), which stipulates differentiated levels that classify the companies from highest to lowest: New Market, Level 2, and Level 1 (Rogers, Sousa Ribeiro, \& Sousa, 2007). After creating the different levels, several empirical studies have been developed to compare these classifications (Aguiar, Corrar, \& Batistella, 2004; Rogers, Sousa Ribeiro, \& Sousa, 2005; Vieira \& Mendes, 2006).

Financial asset pricing models are constantly tested for validity and, consequently, extensions of these models are developed in order to meet the needs found during the investigations. The described relationship between corporate governance and stock returns, as well as stock prices, are relevant to the investigation of corporate governance as an explained factor in financial assets pricing models. Azevedo et al. (2016) added to Fama and French's (1993) CAPM three-factors an enterprise sustainability factor, which was presented as an important explainer in asset pricing models. Likewise, this research intends to investigate the relationship between enterprise sustainability and return, with a focus on binomial corporate governance and return.

This paper asks the following question:

- What is the impact of the inclusion of corporate governance on the explanation of Fama and French's (1993) three-factor model?

The objective of this research is, thus, to analyse the impact of the inclusion of corporate governance on the explanation of Fama and French's (1993) three-factor model.

This paper has its justification in the study of the effect of corporate governance as a provider of the stock returns explanation as relevant to the finance area (Ferreira \& Laux, 2007). It is still justifiable to include a new factor in the financial asset pricing model since Costa et al. (2016) claimed 
that research and analysis of the price behavior of financial assets remain to yearn in many studies. Wernke and Lembeck (2004) claimed that management improvement in organizations sometimes provides for the development of economic and financial models that can produce prominent and beneficial information for decision support.

This research differs from other studies by inserting corporate governance, which prior research indicates is related to stock return, as an explanatory factor in the pricing model of financial assets. This paper contributes to financial research areas by trying to identify some characteristics that have not been explored with the proposed method. This adds an explanation in the pricing model of financial assets, thus assisting researchers and accounting professionals in the financial area.

\section{BACKGROUND}

\subsection{Capital assets pricing models}

Considering asset pricing, Sharpe (1964), Lintner (1965), and Mossin (1966) proposed the CAPM, which relates the return on an asset, discounted at a risk-free rate, and is explained by the return on the market with the same discount rate. This model has some limitations, which generate criticism by professional and academic experts, as there are variables that affect the stock price that were not included in the traditional model. Thus, several authors have proposed alternatives and complementary models to the CAPM that aim to improve its explanation.

Merton (1973) suggested the Intertemporal Capital Asset Pricing Model (ICAPM), a methodology to estimate asset price in an intertemporal way. According to the author, this improved the explanation of CAPM and supplied some of its restrictions. In addition, Fama and French (1993) proposed the three-factor asset pricing model that considered size and market-to-book, a model that has received wide dissemination and empirical validation.

In 2002, Estrada presents the Downside Capital Asset Pricing Model (D-CAPM), which modifies the traditional CAPM by changing the "beta", which is estimated by variance to estimation by semi-variance. According to the authors, this increased the explanation power of this new beta named "downside beta". In their study, Fama and French (2015) proposed a "fivefactor asset pricing model", that included two other factors in the old threefactor model. These authors presented an explanation of the new variables 
(investment and rentability) and added them as explicative in the threefactor model.

Lastly, and with great influence in this paper, Azevedo et al. (2016) proposed the insertion in three-factors CAPM of the corporate sustainability factor. The authors added weighting of sustainability index to Fama and French's $(1993,2015)$ methodology, considering high and low sustainability companies.

The authors assumed the three-factor Fama and French's (1993) model as a base for the new model and included and excluded the factors of market, size, market-to-book, and sustainability. They exchanged the factors in such a way as to generate six different test models, which have been tried for different portfolios by size and book-to-market combined. The study statistically showed the influence of corporate sustainability on the market performance of shares, and that the organizations on ISE showed higher returns.

Similarly, some studies presented in the literature related the stock return with corporate governance (Gompers et al., 2003; Ferreira \& Laux, 2007; Nguyen, 2011; Martins \& Paulo, 2014). Analogous to the study of Azevedo et al. (2016), and considering the relationship testified in the literature between corporate governance and asset price, this paper assumes a model that embodies in its estimate a factor of corporate governance. For Ferreira and Laux (2007), the delimitation and incentives are the practices that governance exerts that influence stock prices, a relationship they saw as relevant to the finance area.

\subsection{Corporate governance}

Corporate governance is considered a mechanism by which external investors save themselves from the power abuses of management (Shleifer \& Vishny, 1986; La Porta et al., 1999; Xu \& Wang, 1999). Leal and Saito (2003) claimed that corporate governance is a set of rules, practices and institutions that determine how managers act where there is a system for the stakeholders to easily monitor those managers. Thus, corporate governance seeks help minimize agency problems occurring between principal and agent (Jensen \& Meckling, 1976; Silveira, Barros, \& Famá, 2003), in addition to providing greater transparency to all involved (Vieira \& Mendes, 2006).

The corporate governance target is to ensure the best relationship between stakeholders, maximizing firm value and shareholders' return (Terra \& Lima, 2006). For Demsetz and Lehn (1985), corporate governance was relevant for investigating a relationship between costs and benefits and 
company performance and value, in addition to market instability, firm size, and capital structure.

The companies that have compromised to adopt better corporate governance standards have been indexed in a specific portfolio on the Corporate Governance Index (CGI) of Bovespa (Rogers et al., 2007). Malacrida and Yamamoto (2006) even claimed that, except for New Market, these companies created the Bovespa's "Differentiated Levels of Corporate Governance", with a target to encourage and prepare the companies to subscribe to New Market level and to highlight company efforts to improve investor relations and raise the potential for appreciation of assets, i.e. the price of shares.

Vieira and Mendes (2006) said there is evidence that corporate governance would influence the reduction of capital cost, once creditors had better confidence in company data and shareholders were willing to invest. Rogers, Securato, and Sousa Ribeiro (2008) confirmed these assumptions, as the results of their study showed that the cost of capital and return of investment were lower for companies with superior corporate governance practices.

Bressan and Bressan (2008) concluded that the average profitability for companies that belong to different levels of corporate governance was higher than the average for non-companies. This demonstrates that a higher level of transparency, and less information asymmetry, enables companies to perform better.

Some studies have countered these results. For Leal and Saito (2003), it was not clear whether adopting best corporate governance practices and transparency significantly increased share value and reduced conflicts of interest. For Camargos and Barbosa (2010), adhering to the different levels of corporate governance did not result in the creation of wealth for shareholders. For Chalevas and Tzovas (2016), the introduction of corporate governance mechanisms was not efficient to increase the share price and did not reflect the fundamental economic value of the company.

\section{METHODOLOGY}

This paper is characterized as descriptive, archival and quantitative. The sample was composed of companies listed in the B3 stock exchange, consisting of 387 firms in the 2012 to 2016 period. These companies were included in the sample because they have public ownership with available and adequate information for the study of corporate governance according to the literature (Vieira, Velasquez, Losekann, \& Ceretta, 2011). Monthly data was used to conduct the research. 
Financial companies were excluded from the sample, in accordance with Fama and French $(1993,2015)$, as they were companies that did not have all the necessary information to construct the model factors, resulting in a final sample of 282 companies. The importance of analyzing the research sample by the new model of Fama and French (2015) was highlighted because it presents an improvement in the pricing of assets, which is highly used in the capital markets, and yet it has not been widely investigated as to its adequacy in emerging markets, such as Brazil. Data was collected from the Thomson Reuters ${ }^{\circledR}$ database.

\subsection{Research model}

The three- and five-factor models proposed by Fama and French (1993, 2015) that were used in this study included factors that considered market effects, size, market-to-book, profitability, and investments. Complementary to this, and explicitly based on the literature, corporate governance has an impact on stock returns. Thus, to test the proposed relationship, and based on the methodology adopted by Azevedo et al. (2016), the inclusion of corporate governance as a factor was considered in parts. In other words, considering the factors studied, a different combination of factors that compose Fama and French's (2015) model was created for analysis and, for those, the corporate governance factor was aggregated.

Modeling was performed to analyze how much each factor incorporates into the explanation of stock returns, and to analyze isolated effects of certain factors. Thus, it was made the comparison for various models, which are weights of the three- and five-factor traditional models. Equation 1 shows the changes that were made.

$$
R_{j}-R_{f}=\beta_{0}+\beta_{1}\left(R_{m}-R_{f}\right)+\gamma \text { FATORES }+\varepsilon_{i}
$$

in which $R_{j}$ is the stock return; $R_{f}$ is the risk-free rate; $R_{m}$ is the market portfolio return; $\gamma$ FATORES is the component with changes on coefficients and factors of the model (SMB, HML, RMW, CMA e GOV); and $\varepsilon_{i}$ is the random error.

In the present study, the portfolio division method was used to test the models that were used in the studies by Fama and French $(1993,2015)$ and Azevedo et al. (2016) that support this paper.

For the composition of the portfolios used, the market value of the sample companies was ranked in ascending order. According to the median 
of this variable, two portfolios were then built, denoted "small" (less than the median) and "big" (higher than the median). Both of these portfolios, small and big, were used to form the four factors of the models:

- $S M B$, the statistical average of stock returns for small companies minus the average of stock returns for big companies;

- $H M L$, which ordered the small and big portfolios according to book-tomarket and subdivided both portfolios into $30^{\circ}$ and $70^{\circ}$ percentiles, where companies below $30^{\circ}$ percentile were denoted "low" and above $70^{\circ}$ percentile, "high", with the rest being "neutral". The final index of HML was the difference between the high and the low portfolio;

- $\quad R M W$, which ordered the small and big portfolios according to the profitability index, subdivided into $30^{\circ}$ and $70^{\circ}$ percentiles, as was the HML factor. The results are the difference between the robust (above $70^{\circ}$ percentile) and the weak (below $30^{\circ}$ percentile);

- $C M A$, which ordered the small and big portfolios according to the investment index; after that, it repeated the process of division into percentiles similar to previous factors. The CMA factor is the difference between the statistical average of stock returns of conservative companies with the average stock return of aggressive companies.

Figure 3.1.1. succinctly shows the variables used.

(Figure 3.1.1)

RESEARCH CONSTRUCT

\begin{tabular}{clc}
\hline Variable & Description & Formula \\
\hline$R_{i}$ & Return of share $i$ in time $t$ & $R_{i}=\frac{R_{i t}-R_{i(t-1)}}{R_{i(t-1)}}$ \\
\hline$R_{f}$ & Risk-free rate & Selic rate \\
\hline$R_{m}$ & Return of market portfolio & Ibovespa Index return \\
\hline$S M B$ & Size factor & $S M B=\frac{(S-B)}{2}$ \\
\hline$H M L$ & Book-to-market factor & $H M L=\frac{(S H-B H)}{2}-\frac{(S L-B L)}{2}$ \\
\hline
\end{tabular}


(Figure 3.1 .1 (conclusion))

RESEARCH CONSTRUCT

\begin{tabular}{|c|c|c|}
\hline Variable & Description & Formula \\
\hline$R M W$ & Profitability factor & $R M W=\frac{(S R-B R)}{2}-\frac{(S W-B W)}{2}$ \\
\hline CMA & Investment factor & $C M A=\frac{(S C-B C)}{2}-\frac{(S A-B A)}{2}$ \\
\hline VM & Market value of firm & $V M=P A * Q A$ \\
\hline$B M$ & Book-to-market of firm & $B M=\frac{\text { Valor de mercado }}{\text { Valor contábil }}$ \\
\hline REN & Profitability of firm & REN $=\frac{\text { Lucro operacional }}{\text { Patrimônio líquido }}$ \\
\hline INV & Investment of firm & INV $=A T_{t}-A T_{t-1}$ \\
\hline
\end{tabular}

S - small portfolio; B - big portfolio; SH - small high; BH - big high; SL - small low; BL - big low; SR-small robust; BR - big robust; SW - small weak; BW - big weak; SC - small conservative; BC - big conservative; SA - small aggressive; BA - big aggressive; SP - share price; QS - quantity of shares; TA - total assets.

Source: Elaborated by the authors.

The model also analyzed a market factor, discounted from the market portfolio return at a risk-free rate, and considered it as a market trend. In addition to these factors already known in the literature, this study also used a corporate governance factor.

The corporate governance factor of this study was based on the different levels of corporate governance already existing in the B3 stock exchange. The factor was built according to different levels: traditional market, Level 1, Level 2, and New Market. To measure the corporate governance factor, four portfolios were crossed with size. Figure 3.1.2 shows the results of the crossing. 


\section{(Figure 3.1.2)}

RETURN OF CORPORATE GOVERNANCE PORTFOLIOS OF B3 ACCORDING TO SIZE QUINTILES

\begin{tabular}{lccccc} 
& Small & 2 & 3 & 4 & Big \\
\hline New Market & -0.0016 & 0.0138 & -0.0237 & 0.0012 & 0.0115 \\
\hline Level 2 & -0.0125 & 0.0219 & -0.0075 & -0.0023 & 0.0081 \\
\hline Level 1 & -0.0629 & 0.0947 & 0.0323 & -0.0151 & -0.0000 \\
\hline Tradition & -0.3104 & 0.0040 & 0.0005 & 0.0107 & 0.0075 \\
\hline
\end{tabular}

Companies that belong in New Market have more returns in the extreme sizes analyzed. Thus, the factor must be estimated by the returns of big and small companies of New Market minus the return of big and small companies into traditional markets. The equation that expresses this final form is shown in Equation 2.

$$
G O V=\frac{(S N+B N)}{2}-\frac{(S T+B T)}{2}
$$

The GOV factor represents the statistical average of stock returns from New Market $(\mathrm{N})$ companies minus the stock returns of traditional market companies $(\mathrm{T})$

\subsection{Research variables}

According to some studies of Capital Asset Pricing, the dependent variables in proposed regression models consist of the risk premium. This study is different from the others by analyzing eight portfolios that fit better with the research objective and support the desired analysis. The portfolios used in this study are outlined in Figure 3.2.1. The data used was monthly from 282 companies, resulting in a total of 15,180 observations. 
(Figure 3.2.1)

PORTFOLIOS FORMED TO MODEL TESTING

\begin{tabular}{lll} 
& \multicolumn{2}{c}{ Size } \\
\cline { 2 - 3 } & Small & Big \\
\hline New Market & SN (2742) & BN (3558) \\
\hline Level 2 & S2 (351) & B2 (549) \\
\hline Level 2 & SI (434) & BI (1126) \\
\hline Traditional & ST (4723) & BT (1697) \\
\hline
\end{tabular}

The values in parenthesis correspond with observations in each portfolio: SN - small New Market; S2 - small Level 2; S1 - small Level 1; ST - small traditional market; BN - big New Market; B2 - big Level 2; B1 - big Level 1; BT - Big traditional market.

Fama and French's (1993) study subdivided the companies in quintiles according to size and book-to-market. When crossing such groups, the authors obtained 25 portfolios. The present study worked with eight different portfolios because there are a smaller number of companies in Brazil than in the American stock exchange.

The portfolios were built using the division into small and big firms, previously performed. Those portfolios were then subdivided into four corporate governance levels (New Market, Level 2, Level 1, and traditional market). Finally, those eight portfolios were used in this study. The Selic interest rate was used as a proxy for the risk-free rate because it is more adequate and is referent to variations in the national bonds trade (Damodaran, 2009). The proxy for the market portfolio was the Ibovespa Index.

Multiple linear regression was used for data analysis, the estimate was by the ordinary least squares method (OLS), since it was used the average return of companies into the portfolio by period to form such used observations by portfolio. The regressions were calculated by Stata software, by model, and by portfolio, with 160 regressions in total.

\section{RESULTS ANALYSIS}

The results converted into a descriptive statistical analysis of explicative variables indicated a mean monthly variation of risk premium of less than $1 \%$, which represented little variation in gains, as shown in Figure 4.1. The 
standard deviation, as the factor with more data homogeneity, confirmed the findings for the same variable. The results had bigger means as compared to the Azevedo et al. (2016) study, evidencing a certain variation and an increase of market after 2013.

\section{(Figure 4.1)}

DESCRIPTIVE STATISTICAL OF EXPLICATIVE VARIABLES

\begin{tabular}{cccccccc}
\hline \multirow{2}{*}{ Premium } & \multirow{2}{*}{ Mean } & \multirow{2}{*}{ SD } & \multicolumn{6}{c}{ Matrix of correlations } \\
\cline { 4 - 8 } & & & $R_{\mathrm{m}}-R_{f}$ & SMB & HML & RMW & CMA \\
\hline$R_{m}-R_{f}$ & 0.0006 & 0.0528 & 1.0000 & & & & \\
\hline SMB & 1.3614 & 13.5017 & 0.0425 & 1.0000 & & & \\
\hline HML & 1.2520 & 8.9676 & 0.6465 & 0.1113 & 1.0000 & & \\
\hline RMW & 2.4065 & 11.5217 & 0.1374 & 0.0787 & 0.2920 & 1.0000 & \\
\hline CMA & 1.3710 & 19.9687 & 0.0003 & 0.0280 & -0.0504 & -0.1185 & 1.0000 \\
\hline GOV & 0.6458 & 10.8922 & -0.0955 & -0.1222 & -0.2309 & -0.1762 & 0.0131 \\
\hline
\end{tabular}

Source: Elaborated by the authors.

The correlations between the study's variables did not indicate problems with self-correlation between them, evidencing no problems with the use of that proposed model. The measured factor of corporate governance presented a similar relationship to the other variables, the same happened with mean and standard deviation. This is shown in Figure 4.2, the model regression assumption used in this paper.

(Figure 4.2)

REGRESSION MODELS ASSUMPTION

\begin{tabular}{cccccc}
\hline Model & Normality & Homoscedasticity & Linearity & Self-correlation & $\begin{array}{c}\text { VIF } \\
\text { (max.) }\end{array}$ \\
\hline 1 & 0.200 & 0.341 & 0.000 & 1.629 & - \\
\hline 2 & 0.452 & 0.345 & 0.000 & 1.656 & 1.009 \\
\hline 3 & 0.195 & 0.395 & 0.000 & 1.678 & 1.779 \\
\hline 4 & 0.513 & 0.345 & 0.000 & 1.654 & 1.024 \\
\hline
\end{tabular}




\section{(Figure 4.2 (conclusion))}

\section{REGRESSION MODELS ASSUMPTION}

\begin{tabular}{cccccc}
\hline Model & Normality & Homoscedasticity & Linearity & Self-correlation & $\begin{array}{c}\text { VIF } \\
\text { (max.) }\end{array}$ \\
\hline 5 & 0.545 & 0.395 & 0.000 & 1.681 & 1.850 \\
\hline 6 & 0.542 & 0.395 & 0.000 & 1.678 & 1.864 \\
\hline 7 & 0.553 & 0.399 & 0.000 & 1.671 & 1.916 \\
\hline 8 & 0.098 & 0.711 & 0.011 & 0.950 & 1.006 \\
\hline 9 & 0.132 & 0.164 & 0.047 & 0.665 & 1.001 \\
\hline 10 & 0.555 & 0.395 & 0.000 & 1.670 & 1.895 \\
\hline 11 & 0.544 & 0.398 & 0.000 & 1.685 & 1.765 \\
\hline 12 & 0.512 & 0.349 & 0.000 & 1.661 & 1.024 \\
\hline 13 & 0.213 & 0.343 & 0.000 & 1.651 & 1.051 \\
\hline 14 & 0.196 & 0.398 & 0.000 & 1.685 & 1.858 \\
\hline 15 & 0.183 & 0.394 & 0.000 & 1.672 & 1.965 \\
\hline 16 & 0.554 & 0.395 & 0.000 & 1.667 & 1.912 \\
\hline 17 & 0.543 & 0.398 & 0.000 & 1.682 & 1.788 \\
\hline 18 & 0.555 & 0.394 & 0.000 & 1.671 & 1.977 \\
\hline 19 & 0.452 & 0.398 & 0.000 & 1.682 & 1.873 \\
\hline 20 & 0.554 & 0.399 & 0.000 & 1.674 & 1.980 \\
\hline
\end{tabular}

The serial normality test (Kolmogorov-Smirnov); the homoscedasticity test (Pesarán-Pesarán); coefficients linearity (ANOVA); serial self-correlation test (Durbin-Watson); multicollinearity statistic (VIF).

\section{Source: Elaborated by the authors.}

It is possible to observe from Figure 4.2 that every model attends the assumptions to use the OLS regression. Figure 4.3, in turn, explains the coefficients obtained by the tests proposed in this paper according to associated premiums. The risk premium that represents how stock returns are associated with the market return was statistically significant for every proposed model to indicate that for each point that the market goes up or down, the same happens with stock return. The portfolio composed of small firms belonging to the New Market level had every coefficient for every model significate to factors, with the exception of corporate governance. 
In the portfolio composed of small companies in Level 2 of the corporate governance index, there was not a model with every coefficient significant, except for the traditional model. The same analysis is true for small companies in Level 1 of the corporate governance index and big companies in Level 2 of corporate governance from B3.

\section{(Figure 4.3)}

\section{MODEL COMPARISON}

$R_{j}-R_{f}=a+b\left(R_{m}-R_{f}\right)+s(S M B)+h(H M L)+r(R M W)+c(C M A)+g(G O V)+\varepsilon_{i}$

\begin{tabular}{|c|c|c|c|c|c|c|c|c|c|}
\hline Model & Coef. & SN & S2 & S1 & ST & $\mathrm{BN}$ & $\mathrm{B} 2$ & B1 & BT \\
\hline$(1)$ & b & $1.00^{\star}$ & $1.00^{\star}$ & $0.99 *$ & $1.00^{\star}$ & $0.97^{\star}$ & $1.00^{\star}$ & $0.99^{\star}$ & $0.99^{\star}$ \\
\hline \multirow[t]{2}{*}{ (2) } & b & $1.00 *$ & $1.00^{*}$ & $0.99 *$ & $1.00^{\star}$ & $0.98^{*}$ & $1.00^{*}$ & $0.99 *$ & $0.99 *$ \\
\hline & g & 0.39 & 0.19 & -0.41 & $-0.94^{*}$ & $1.82^{\star \star \star}$ & -0.08 & $0.69^{\star}$ & -0.03 \\
\hline \multirow[t]{3}{*}{ (3) } & $b$ & $1.00 *$ & $1.01^{\star}$ & $1.01^{\star}$ & $1.00 *$ & $1.03^{\star}$ & $1.00 *$ & $1.01^{\star}$ & $1.00^{\star}$ \\
\hline & s & 0.15 & 0.04 & 0.01 & 0.02 & -1.27 & 0.18 & $-0.65^{\star}$ & $0.10^{*}$ \\
\hline & h & $-0.42^{*}$ & -0.38 & -0.79 & -0.08 & $-3.96^{\star}$ & 0.08 & -0.37 & $-0.66^{\star}$ \\
\hline \multirow[t]{3}{*}{ (4) } & b & $1.00^{*}$ & $1.00^{*}$ & $1.00^{*}$ & $1.00^{*}$ & $1.00^{*}$ & $1.00^{*}$ & $1.00^{*}$ & $0.99 *$ \\
\hline & s & 0.01 & 0.03 & -0.03 & 0.01 & $-2.88^{*}$ & 0.19 & $-0.83^{\star}$ & $0.10^{\star}$ \\
\hline & g & 0.04 & 0.21 & -0.41 & $-0.93^{\star}$ & -1.01 & 0.02 & -0.21 & 0.06 \\
\hline \multirow[t]{3}{*}{ (5) } & b & $1.00^{\star}$ & $1.00 *$ & $1.00^{\star}$ & $1.00 *$ & $1.03^{\star}$ & $1.00 *$ & $1.00^{\star}$ & $1.00^{\star}$ \\
\hline & h & $-0.42^{*}$ & -0.32 & -0.91 & $-0.28^{\star \star}$ & $-5.12^{\star}$ & 0.06 & $-0.90^{\star}$ & $-0.61^{*}$ \\
\hline & g & -0.04 & 0.13 & -0.57 & $-0.99 *$ & 0.26 & -0.08 & $0.41^{\star \star \star}$ & -0.15 \\
\hline \multirow[t]{4}{*}{ (6) } & b & $1.00 *$ & $1.00^{*}$ & $1.01^{*}$ & $1.00^{*}$ & $1.03^{*}$ & $1.00^{*}$ & $1.01^{*}$ & $1.00^{*}$ \\
\hline & s & 0.01 & 0.04 & 0.01 & 0.01 & -1.69 ** & 0.20 & $-0.72^{\star}$ & $0.10^{*}$ \\
\hline & h & $-0.43^{\star}$ & -0.35 & -0.91 & $-0.29 * \star$ & $-3.97^{\star}$ & 0.09 & -0.37 & $-0.67^{*}$ \\
\hline & g & -0.03 & 0.15 & -0.57 & $-0.99 *$ & -1.05 & 0.03 & -0.21 & -0.07 \\
\hline \multirow[t]{5}{*}{ (7) } & b & $1.00^{*}$ & $1.00^{*}$ & $1.00^{\star}$ & $1.00^{\star}$ & $1.03^{\star}$ & $1.00^{*}$ & $1.01^{*}$ & $1.00^{\star}$ \\
\hline & s & 0.01 & 0.04 & 0.01 & 0.02 & $-1.42^{\star \star}$ & 0.19 & $-0.62^{\star}$ & $0.10^{*}$ \\
\hline & h & $-0.40^{\star \star}$ & -0.32 & -0.97 & -0.10 & $-4.35^{\star}$ & 0.08 & -0.33 & $-0.67^{*}$ \\
\hline & $r$ & 0.01 & -0.19 & 0.55 & 0.11 & $2.03^{\star}$ & 0.13 & -0.24 & 0.07 \\
\hline & c & $0.47^{\star \star *}$ & 0.19 & -0.31 & 0.22 & 0.17 & 0.01 & 0.06 & 0.20 \\
\hline \multirow[t]{3}{*}{ (8) } & $b$ & $1.00^{\star}$ & $1.01^{*}$ & $1.00^{\star}$ & $1.00^{*}$ & $1.00^{\star}$ & $1.00^{\star}$ & $1.00^{*}$ & $0.99 *$ \\
\hline & s & 0.01 & 0.03 & -0.02 & 0.02 & $-2.68^{*}$ & 0.19 & $-0.71^{\star}$ & $0.10^{*}$ \\
\hline & r & -0.14 & -0.29 & 0.32 & 0.06 & $1.557^{\star \star \star \star}$ & 0.13 & -0.28 & -0.11 \\
\hline \multirow[t]{3}{*}{ (9) } & b & $1.00^{\star}$ & $1.00^{\star}$ & $1.00^{*}$ & $1.00^{*}$ & $1.00^{*}$ & $1.00^{*}$ & $1.00^{\star}$ & $0.99^{\star}$ \\
\hline & s & 0.01 & 0.03 & 0.01 & 0.02 & $-2.46^{\star}$ & 0.18 & $-0.75^{\star}$ & $0.10^{*}$ \\
\hline & c & $0.50^{\star \star}$ & 0.24 & -0.33 & 0.21 & 0.22 & -0.01 & 0.12 & 0.25 \\
\hline
\end{tabular}




\section{(Figure 4.3 (continuation))}

MODEL COMPARISON

\begin{tabular}{|c|c|c|c|c|c|c|c|c|c|}
\hline Model & Coef. & SN & $\mathrm{S2}$ & S1 & ST & $\mathrm{BN}$ & $\mathrm{B} 2$ & B1 & BT \\
\hline \multirow[t]{3}{*}{ (10) } & $b$ & $1.00 *$ & $1.00 *$ & $1.00 *$ & $1.00 *$ & $1.03^{\star}$ & $1.00^{\star}$ & $1.00^{\star}$ & $1.00^{\star}$ \\
\hline & $\mathrm{h}$ & $-0.40^{\star \star}$ & -0.29 & -0.95 & -0.10 & $-5.75^{\star}$ & 0.06 & $-0.96 *$ & $-0.61^{*}$ \\
\hline & $r$ & -0.03 & -0.19 & 0.58 & 0.10 & $1.83^{\star \star}$ & 0.11 & $-0.41^{\star \star \star}$ & 0.10 \\
\hline \multirow[t]{3}{*}{ (11) } & $b$ & $1.00^{\star}$ & $1.00^{\star}$ & $1.00^{*}$ & $1.00^{*}$ & $1.03^{*}$ & $1.00^{\star}$ & $1.00^{\star}$ & $1.00^{\star}$ \\
\hline & h & $-0.39 *$ & -0.34 & -0.80 & -0.06 & $-5.26^{\star}$ & 0.06 & $-1.07^{\star}$ & $-0.57^{\star}$ \\
\hline & c & $0.47^{\star \star *}$ & 0.23 & -0.38 & 0.21 & -0.25 & -0.01 & 0.01 & 0.23 \\
\hline \multirow[t]{4}{*}{ (12) } & $b$ & $1.00^{\star}$ & $1.00^{*}$ & $1.00^{*}$ & $1.00^{*}$ & $1.00^{*}$ & $1.00^{*}$ & $1.00^{\star}$ & $0.99^{\star}$ \\
\hline & s & 0.01 & 0.03 & -0.01 & 0.01 & $-2.87^{\star}$ & 0.19 & $-0.83^{\star}$ & $0.10^{*}$ \\
\hline & c & $0.49 * *$ & 0.23 & -0.31 & 0.25 & 0.22 & -0.01 & 0.11 & 0.24 \\
\hline & g & 0.03 & 0.21 & -0.40 & $-0.94^{\star}$ & 1.01 & 0.02 & -0.21 & 0.06 \\
\hline \multirow[t]{4}{*}{ (13) } & b & $1.00^{*}$ & $1.00^{\star}$ & $1.00^{\star}$ & $1.00^{\star}$ & $1.00^{\star}$ & $1.00^{\star}$ & $1.00^{\star}$ & $0.99^{*}$ \\
\hline & s & 0.01 & 0.04 & -0.01 & 0.01 & $-3.02^{*}$ & 0.20 & $-0.78^{\star}$ & $0.10^{*}$ \\
\hline & $r$ & -0.14 & -0.026 & 0.25 & -0.12 & $1.50^{\star \star \star}$ & 0.13 & -0.27 & -0.10 \\
\hline & g & 0.02 & 0.17 & -0.37 & $-0.96^{\star}$ & -0.84 & 0.02 & -0.19 & 0.04 \\
\hline \multirow[t]{4}{*}{ (14) } & b & $1.00^{*}$ & $1.00^{*}$ & $1.01^{*}$ & $1.00^{\star}$ & $1.03^{*}$ & $1.00^{\star}$ & $1.00^{\star}$ & $1.00^{*}$ \\
\hline & h & $-0.41^{\star \star}$ & -0.27 & -1.04 & $-0.27^{\star \star \star}$ & $-5.55^{\star}$ & 0.05 & $-0.81^{\star}$ & $-0.63^{*}$ \\
\hline & $r$ & -0.03 & -0.18 & 0.50 & -0.05 & $1.89 * \star$ & 0.12 & $-0.38^{\star \star \star}$ & 0.08 \\
\hline & g & -0.04 & 0.11 & -0.55 & $-1.00^{*}$ & 0.52 & -0.08 & $0.38^{\star \star \star}$ & -0.14 \\
\hline \multirow[t]{4}{*}{ (15) } & $b$ & $1.00^{*}$ & $1.00^{*}$ & $1.01^{\star}$ & $1.00^{*}$ & $1.03^{\star}$ & $1.00^{\star}$ & $1.00^{\star}$ & $1.00^{*}$ \\
\hline & h & $-0.40^{\star \star}$ & -0.31 & -0.92 & $-0.27^{\star \star}$ & $-5.15^{\star}$ & 0.06 & $-0.90^{\star}$ & $-0.60^{\star}$ \\
\hline & c & $0.47^{\star \star}$ & 0.23 & -0.37 & 0.23 & -0.24 & -0.02 & 0.04 & 0.24 \\
\hline & g & -0.04 & 0.13 & -0.57 & $-0.99^{*}$ & 0.26 & -0.08 & $0.41^{\star \star \star}$ & -0.15 \\
\hline \multirow[t]{4}{*}{ (16) } & $b$ & $1.00^{*}$ & $1.00^{*}$ & $1.00^{*}$ & $1.00^{*}$ & $1.03^{*}$ & $1.00^{*}$ & $1.00^{*}$ & $1.00^{*}$ \\
\hline & s & 0.01 & 0.04 & 0.01 & 0.02 & $-1.42^{\star \star}$ & 0.19 & $-0.62^{\star}$ & $0.10^{*}$ \\
\hline & h & $-0.41^{\star \star}$ & -0.32 & -0.96 & -0.11 & $-4.37^{\star}$ & 0.08 & -0.34 & $-0.67^{\star}$ \\
\hline & r & -0.03 & -0.21 & 0.58 & 0.09 & $2.02^{\star}$ & 0.13 & -0.25 & 0.06 \\
\hline \multirow[t]{4}{*}{ (17) } & b & $1.00^{*}$ & $1.00 *$ & $1.01^{\star}$ & $1.00^{*}$ & $1.03^{\star}$ & $1.00 *$ & $1.00^{\star}$ & $1.00^{\star}$ \\
\hline & s & 0.01 & 0.04 & 0.01 & 0.02 & $-1.26^{\star \star}$ & 0.18 & $-0.65^{\star}$ & $0.10^{*}$ \\
\hline & h & $-0.40^{\star}$ & -0.37 & -0.81 & -0.07 & $-3.98^{\star}$ & 0.08 & -0.36 & $-0.65^{\star}$ \\
\hline & c & $0.46^{\star \star}$ & 0.21 & -0.39 & 0.20 & -0.19 & -0.01 & 0.08 & 0.19 \\
\hline \multirow[t]{5}{*}{ (18) } & b & $1.00^{*}$ & $1.00 *$ & $1.01^{\star}$ & $1.00 *$ & $1.03^{\star}$ & $1.00 *$ & $1.01^{\star}$ & $1.00^{\star}$ \\
\hline & s & 0.01 & 0.04 & 0.01 & 0.01 & $-1.75^{\star}$ & 0.21 & $-0.69^{\star}$ & $0.10^{\star}$ \\
\hline & h & $-0.41^{*}$ & -0.30 & -1.05 & $-0.28^{\star \star}$ & $-4.36^{\star}$ & 0.08 & -0.34 & $-0.68^{\star}$ \\
\hline & c & $0.47^{\star \star}$ & -0.19 & 0.50 & -0.05 & $1.96^{\star}$ & 0.13 & -0.24 & 0.05 \\
\hline & $g$ & -0.04 & 0.13 & -0.51 & $-0.99^{*}$ & -0.83 & 0.02 & -0.20 & -0.06 \\
\hline
\end{tabular}




\section{(Figure 4.3 (conclusion))}

\section{MODEL COMPARISON}

\begin{tabular}{|c|c|c|c|c|c|c|c|c|c|}
\hline Model & Coef. & SN & $S 2$ & S1 & ST & BN & B2 & B1 & BT \\
\hline \multirow[t]{5}{*}{ (19) } & b & $1.00^{*}$ & $1.00 *$ & $1.00 *$ & $1.00 *$ & $1.03^{*}$ & $1.00 *$ & $1.01^{\star}$ & $1.00 *$ \\
\hline & s & 0.01 & 0.04 & 0.01 & 0.01 & $-1.69^{\star \star}$ & 0.20 & $-0.73^{*}$ & $0.10^{\star}$ \\
\hline & h & $-0.42^{\star \star}$ & -0.34 & -0.93 & $-0.28^{\star \star}$ & -3.99* & 0.09 & -0.37 & $-0.66^{\star}$ \\
\hline & $r$ & -0.04 & 0.21 & -0.37 & 0.23 & -0.19 & -0.01 & 0.08 & 0.19 \\
\hline & g & -0.04 & 0.15 & -0.57 & $-0.99^{\star}$ & -1.05 & 0.03 & -0.21 & -0.07 \\
\hline \multirow[t]{6}{*}{ (20) } & b & $1.00^{*}$ & $1.01^{\star}$ & $1.01^{\star}$ & $1.00^{*}$ & $1.03^{*}$ & $1.00^{*}$ & $1.00^{*}$ & $1.00^{\star}$ \\
\hline & s & 0.01 & 0.04 & 0.01 & 0.01 & $-1.76^{\star}$ & 0.21 & $-0.69^{\star}$ & $0.10^{\star}$ \\
\hline & h & $-0.41^{\star \star}$ & -0.29 & -1.05 & $-0.27^{\star \star}$ & $-4.35^{\star}$ & 0.08 & -0.33 & $-0.68^{\star}$ \\
\hline & $r$ & -0.01 & -0.18 & 0.48 & -0.03 & $1.98^{\star}$ & 0.13 & -0.24 & 0.06 \\
\hline & c & $0.47^{\star \star}$ & 0.19 & -0.31 & 0.22 & 0.16 & 0.01 & 0.06 & 0.20 \\
\hline & g & -0.04 & 0.13 & -0.51 & $-0.99 *$ & -0.83 & 0.03 & -0.20 & -0.06 \\
\hline
\end{tabular}

*, ** and ${ }^{* \star *}$ significant in level of 1\%, 5\% and 10\%, respectively. Portfolio: SN - small-New Market; S2 - small-Level 2 S1 - small Level 1; ST - small traditional market; BN - big New Market; B2 - big Level 2; B1 - big Level 1; BT - big traditional market.

Source: Elaborated by the authors.

The portfolio formed by small firms that were not in any different levels of corporate governance has the models 1,2 and 5 with significant coefficients. Model 2 was formed by the market factor together with the corporate governance factor, and model 5 added to model 2 the book-tomarket factor. That portfolio had a great number of significant coefficients and it was unique because the corporate governance factor was significant in every tested model. The relationship between corporate governance and the companies of this portfolio was inverse, indicating that the bigger the corporate governance level, the less stock return for the firm.

The big companies in the New Market portfolio had significance in models 1, 2, 8, and 9. Models 1 and 2 are just different due to the addition of the corporate governance factor, indicating that there is a relationship between corporate governance and the market factor in stock returns of Brazilian companies with big size and at the highest levels of corporate governance.

Large companies belonging to the Level 2 of corporate governance had models 5, 10, and 14 with every coefficient significant. Book-to-market had significant coefficients in three models, proving relevant to the portfolios. 
None of the portfolios in the traditional market with Small size had significant coefficients to profitability factor; this factor loaded only to Big companies with any different corporate governance level. This confirms Bressan and Bressan's (2008), who concluded that the mean profitability of companies in different corporate governance levels was higher than in firms without corporate governance.

Other than in model 1, big firms out of CGI of B3 had only the traditional model of CAPM three-factors with every coefficient significant. However, the portfolio had no model with the corporate governance coefficient significant. It stands out that the Big companies with different levels of corporate governance had significant and positive relationships with stock returns, showing that the bigger the corporate governance, the bigger the stock return. These results confirm the studies of Gompers et al. (2003), and Cremers and Nair (2005) in which corporate governance influenced the stock price.

It is also noteworthy that the coefficients of the test models had greater significance from Big companies, indicating a failure in the theoretical prediction for smaller companies. Thus, the evidence of the present research corroborates Ferreira and Laux's (2007) who postulated the influence of corporate governance on stock returns.

The explanatory power of the 20 test models was high, explaining approximately $99 \%$ for each model. This may be motivated by a large number of variables that best fit the assumptions, given the characteristics of each market, which allowed the efficiency of its explanatory power to be increased (Araújo, Oliveira, \& Silva, 2012). It is evident that all significance ( $p$-value) of the regression models was significant at $1 \%$ level ( $p$-value $<0.01)$.

This study corroborates other studies, such as Raboni, Silva Neto Maranhão, and Araújo Filho's (2008), who stated that the CAPM presented better explanatory power when another variable was added. Castro Júnior and Yoshinaga (2012) included new factors in the explanation of the CAPM model and obtained better performance.

For Machado and Medeiros (2012), the five-factor model, composed by the factors of market beta, size, book-to-market, and momentum, showed explanatory power superior to the CAPM and Fama and French's (1993) three-factor models. Similarly, Azevedo et al. (2016) added the sustainability factor, which improved the explanatory power of returns.

According to Araújo et al. (2012), research in Brazil in recent years that sought to study the CAPM and its variants occurred through different approaches. Thus, results are generated that have contributed to the 
understanding of their behavior in this market. Finally, it is noteworthy that agreement can be inferred from these results between the empirical findings and the statement by Terra and Lima (2006), that governance ensures the correct relationship between stakeholders, which maximizes the value of the company and the return of shareholders. Thus, corporate governance minimizes agency problems (Silveira et al., 2003) and provides greater transparency (Vieira \& Mendes, 2006), which explains the increased return of companies with greater governance.

\subsection{Discussion of results}

Regarding the variables, the results related to market value (SMB) indicate that big companies in the traditional market have this value positively related to stock returns; and Big companies belonging to the New Market and Level 1 have an inverse relationship, indicating that when stock returns increase, the market value decreases. As for book-to-market (HML), this influence generally affects the companies with the highest and lowest level of corporate governance; that is, the two extremes. This relationship indicates for the highlighted companies that the higher the Book-to-Market index, the lower the stock return.

The findings regarding profitability (RMW) indicate that it has a greater (positive) impact on Big companies with high corporate governance, thus corroborating the findings of Bressan and Bressan (2008) that profitability is higher for companies with different corporate governance levels, demonstrating that a higher level of transparency and less information asymmetry enables companies to perform better. Regarding investment (CMA), the results indicate that it has greater relevance for the analysis of companies in the New Market index. This is in accordance with Rogers et al. (2008) since their results showed that investment is lower for companies with superior corporate governance practices.

Finally, corporate governance (GOV) was significant in some test models, and it was found that corporate governance is only relevant to New Market companies when combined with the factor that weights the market factor. These findings corroborate Gompers et al. (2003), Cremers and Nair (2005), and Ferreira and Laux (2007), who found the same positive relationship between the variables. The portfolio of Small companies belonging to the Traditional Market, without corporate governance index, obtained an inverse relationship between the corporate governance factor and stock returns, corroborating Chalevas and Tzovas (2016). These authors claimed that the 
corporate governance mechanisms were not efficient for stock prices, and did not reflect the fundamental economic value of the company.

This highlights the importance of the results of this study, given that it was found that corporate governance impacts negatively on the return of shares of small companies and positively on the return of shares of big companies. Thus, the larger the company, the greater the impact on the return on its actions of the differentiated levels of governance. The same is not true for small companies, as corporate governance does not have a positive impact on these stocks returns. It can be inferred that this may be because small companies do not have consolidated governance mechanisms.

\section{FINAL CONSIDERATIONS}

Considering the importance of corporate governance for external users and its possible influence on stock prices, as well as their return, the aim of this study was to analyze the impact of the inclusion of corporate governance on the explanation of Fama and French's $(1993,2015)$ three and five-factor model. The literature on capital assets pricing models is constantly updated and complemented by empirical verifications that aim to prove and improve the propositions and results of traditional models. The present study contributes to this literature by proving an improvement in the explanation of stock returns by using corporate governance.

This paper also contributes to the desire to analyze the behavior of financial asset prices, investigating and confirming the relationship between corporate governance and stock returns. Following the increasingly frequent need for adaptation and further development of models that take into account the relevant information, this results in beneficial and prominent information to support decision making.

The findings show that companies that are managed transparently and with care and concern about the consequences of their actions towards all involved have a positive relationship with the return of action, which declines when compared to lower levels of governance. The findings are confirmed in Fama and French's $(1993,2015)$ three- and five-factor test models. It also proves the importance of efforts to promote best corporate governance practices, since, in addition to having relevance in the organizational context, corporate governance practices influence stock returns and, consequently, the value of companies.

In addition, there is evidence of the adequacy of the traditional CAPM model for the Brazilian market, since in the 20 models tested the only factor 
that maintained constant significance regardless of the variation of factor combinations was the risk premium factor $\left(R_{m}-R_{f}\right)$, proposed in the initial asset pricing model. Emphasis is also placed on the greater ability of prediction and adequacy of pricing models for larger companies since the factors maintained a greater constancy of significance for the portfolios that comprised the Big companies.

This evidence derives from the fact that these companies most closely resemble those of the market in which the initial models were developed. Consequently, Small companies lose some of the explanatory power of the model, since they do not represent this set of companies, and, for this reason, further research is suggested to investigate these companies in particular and highlight the model that can best predict their returns.

This study is intended to contribute to the research area by trying to identify previously unexplored characteristics, not as to the proposed method, that helps add an explanation in the pricing model of financial assets, thus assisting researchers and accounting professionals in the financial area. This study has some limitations. First, companies were not separated by sectors, which could result in different results. In addition, financial companies were excluded from the sample, and research that studies only this sector may be interesting. Other pricing models could also be used, and tested, as there are others, such as ICAPM and DCAPM. Finally, the portfolios could have been separated by a methodology other than the one used in this study, and studies that do so are encouraged.

\section{MODELOS DE PRECIFICAÇÃO DE ATIVOS FINANCEIROS E GOVERNANÇA CORPORATIVA}

\section{RESUMO}

Objetivo: Este estudo teve como objetivo analisar a inclusão da governança corporativa na explicação dos modelos de precificação de ativos de três e cinco fatores de Fama e French $(1993,2015)$.

Originalidade/valor: A presente investigação se diferencia dos demais trabalhos por inserir a governança corporativa como fator explicativo nos modelos de precificação de ativos financeiros. Pretende-se, assim, contribuir para a área de pesquisa ao tentar identificar características 
antes não exploradas, quanto ao método proposto, que agreguem explicação aos modelos de precificação de ativos financeiros, de modo a ajudar os investidores e profissionais da área financeira.

Design/metodologia/abordagem: A amostra de pesquisa é composta por 387 empresas listadas na B3, no período entre 2012 e 2016. Para análise dos dados, utilizaram-se regressões de dados em painel, de acordo com metodologia dos estudos de Fama e French $(1993,2015)$, por meio do software Stata.

Resultados: Os resultados indicam que a governança corporativa impacta negativamente o retorno das ações das pequenas empresas com menores níveis de governança corporativa e que o inverso acontece em relação às grandes empresas, com altos níveis de governança. Outras variáveis também foram encontradas como impactantes no retorno das ações, como valor de mercado, book-to-market, rentabilidade e investimentos.

\section{PALAVRAS-CHAVE}

Risco. Retorno. Governança corporativa. Novo Mercado. Capital Asset Pricing Model.

\section{$\int$ REFERÊNCIAS}

Aguiar, A. B., Corrar, L. J., \& Batistella, F. D. (2004). Adoção de práticas de governança corporativa e o comportamento das ações na Bovespa: Evidências empíricas. Revista de Administração, 39(4), 338-347.

Araújo, E. A. T., Oliveira, V. C., \& Silva, W. A. C. (2012). CAPM em estudos brasileiros: Uma análise da pesquisa. Revista de Contabilidade e Organizações, 6(15). doi: 10.11606/rco.v6i15.52659

Azevedo, V. G., Santos, A. A. P., \& Campos, L. M. S. (2016). Corporate sustainability and asset pricing models: Empirical evidence for the Brazilian stock market. Production, 26(3), 516-526. doi:10.1590/0103-6513.201115

Bhagat, S., \& Bolton, B. (2019). Corporate governance and firm performance: The sequel. Journal of Corporate Finance, 58, 142-168. doi:10.1016/ j.jcorpfin.2019.04.006 
Bressan, V. G. F., \& Bressan, A. A. (2008). Existe diferença entre a rentabilidade das ações das empresas que adotam governança corporativa com relação às empresas do mercado tradicional? Organizações Rurais \& Agroindustriais, $10(2)$.

Camargos, M. A., \& Barbosa, F. V. (2010). A adoção de práticas diferenciadas de governança corporativa beneficia o acionista e aumenta a liquidez acionária? REGE - Revista de Gestão, 17(2), 189-208.

Castro Junior, F. H. F., \& Yoshinaga, C. E. (2012). Coassimetria, cocurtose e as taxas de retorno das ações: Uma análise com dados em painel. Revista de Administração Mackenzie, 13(1), 110-144. doi:10.1590/s1678-6971201200 0100006

Chalevas, C., \& Tzovas, C. (2016). Do stock prices reflect regulatory reforms in the corporate governance mechanisms? The case of Greece. Corporate Ownership \& Control, 13(2-2), 419-431. doi:10.22495/cocv13i2c2p2

Ciftci, I., Tatoglu, E., Wood, G., Demirbag, M., \& Zaim, S. (2019). Corporate governance and firm performance in emerging markets: Evidence from Turkey. International Business Review, 28(1), 90-103. doi:10.1016/j.ibusrev. 2018.08.004

Costa, H. C., Mazzeu, J. H. G., \& Costa Jr., N. C. A. (2016). O comportamento dos componentes da volatilidade das ações no Brasil. Revista Brasileira de Finanças, 14(2), 225-268.

Cremers, K. J., \& Nair, V. B. (2005). Governance mechanisms and equity prices. The Journal of Finance, 60(6), 2859-2894. doi:10.1111/j.1540-6261. 2005.00819.x

Damodaran, A. (2009). Volatility rules: Valuing emerging market companies. SSRN Electronic Journal. doi: 10.2139/ssrn.1609797

Demsetz, H., \& Lehn, K. (1985). The structure of corporate ownership: Causes and consequences. Journal of Political Economy, 93(6), 1155-1177.

Estrada, J. (2002). Systematic risk in emerging markets: the D-CAPM. Emerging Markets Review, 3(4), 365-379. doi:10.1016/S1566-0141(02) 00042-0

Fama, E. F., \& French, K. R. (1992). The cross-section of expected stock returns. The Journal of Finance, 47(2), 427-465. doi:10.1111/j.1540-6261. 1992.tb04398.x

Fama, E., \& French, K. (1993). Common risk factors in the returns on stocks and bonds. Journal of Financial Economics, 33(1), 3-56. doi:10.1016/0304405X(93) $90023-5$ 
Fama, E., \& French, K. (2015). A five-factor asset pricing model. Journal of Financial Economics, 116(1), 1-t22. doi:10.1016/j.jfineco.2014.10.010

Ferreira, M. A., \& Laux, P. A. (2007). Corporate governance, idiosyncratic risk, and information flow. The Journal of Finance, 62 (2), 951-989. doi:10.11 11/j.1540-6261.2007.01228.x

Fonseca, C. V. C., Silveira, R. L. F., \& Hiratuka, C. (2016). A relação entre a governança corporativa e a estrutura de capital das empresas brasileiras no período 2000-2013. Enfoque: Reflexão Contábil, 35(2), 35-52. doi: 10.4025/ enfoque.v35i2.29673.

Fox, M. B., Gilson, R. J., \& Palia, D. (2016). Corporate governance changes as a signal: Contextualizing the performance link. European Corporate Governance Institute [Working Paper n. 323], Stanford Law and Economics Olin [Working Paper n. 496]. doi:10.2139/ssrn.2807926

Freitas, G. A., Silva, E. M., Oliveira, M. C., Aquino Cabral, A. C., \& Santos, S. M. dos (2018). Governança corporativa e desempenho dos bancos listados na B3 em ambiente de crise econômica. Revista Contabilidade, Gestão e Governança, 21 (1), 100-119. doi:10.21714/1984-3925_2018v21n1a6

Gompers, P., Ishii, J., \& Metrick, A. (2003). Corporate governance and equity prices. The Quarterly Journal of Economics, 118(1), 107-156. doi: 10.1162/00 335530360535162

Jensen, M. C., \& Meckling, W. H. (1976). Theory of the firm: Managerial behavior, agency costs and ownership structure. Journal of Financial Economics, 3(4), 305-360. doi:10.1016/0304-405X(76)90026-X

La Porta, R. L., Lopez-de-Silanes, F., Shleifer, A., \& Vishny, R. W. 1999. Investor protection: Origins, consequences, and reform. [Working Paper n. 7428], National Bureau of Economic Research. doi:10.3386/w7428

Leal, R. P. C., \& Saito, R. (2003). Finanças corporativas no Brasil. RAE eletrônica, 2(2), 1-15.

Lintner, J. (1965). The valuation of risk assets and the selection of risky investments in stock portfolios and capital budgets. The Review of Economics and Statistics, 47(1), 13-37. doi:10.1016/B978-0-12-780850-5.50018-6

Lopes, A. B., \& Walker, M. (2012). Asset revaluations, future firm performance and firm-level corporate governance arrangements: New evidence from Brazil. The British Accounting Review, 44(2), 53-67. doi:10.1016/j. bar.2012.03.007

Machado, M. A. V., \& Medeiros, O. R. (2012). Existe o efeito liquidez no mercado acionário brasileiro? Brazilian Business Review, 9(4). 
Malacrida, M. J. C., \& Yamamoto, M. M. (2006). Governança corporativa: Nível de evidenciação das informações e sua relação com a volatilidade das ações do Ibovespa. Revista Contabilidade \& Finanças, 17, 65-79. doi:10.1590/ S1519-70772006000400006

Markowitz, H. (1952). Portfolio selection. The Journal of Finance, 7(1), 77-91. doi:10.1111/j.1540-6261.1952.tb01525.x

Martins, O. S., \& Paulo, E. (2014). Assimetria de informação na negociação de ações, características econômico-financeiras e governança corporativa no mercado acionário brasileiro. Revista Contabilidade \& Finanças, 25(64), 33-45. doi:10.1590/S1519-70772014000100004

Mendonça, F. P., Klotzle, M. C., Pinto, A. C. F., \& Silva Montezano, R. M. (2012). A relação entre risco idiossincrático e retorno no mercado acionário brasileiro. Revista Contabilidade \& Finanças, 23 (60), 246-257. doi:10.15 90/S1519-70772012000300009.

Merton, R. (1973). A simple model of capital market equilibrium with incomplete information. Journal of Finance, 42 (3), 483-510. doi:10.1111/j. 1540-6261.1987.tb04565.x

Mossin, J. (1966). Equilibrium in a capital asset market. Econometrica: Journal of the Econometric Society, 34(4), 768-783. doi:10.2307/1910098.

Nguyen, P. (2011). Corporate governance and risk-taking: Evidence from Japanese firms. Pacific-Basin Finance Journal, 19(3), 278-297. doi:10.1016/j. pacfin.2010.12.002

Raboni, P. L., Silva Neto, O. S., Maranhão, V. L. A., \& Araújo Filho, L. F. C. (2008). Testando um "mito de investimento": Eficácia da estratégia de investimento em ações de crescimento. Anais do Encontro da Associação Nacional de Pós-graduação e Pesquisa em Administração, Rio de Janeiro, RJ, Brasil, 32.

Rogers, P., Securato, J. R., \& Sousa Ribeiro, K. C. (2008). Governança corporativa, custo de capital e retorno do investimento no Brasil. REGE - Revista de Gestão, 15(1), 61-77. doi:10.5700/issn.2177-8736.rege.2008.36630

Rogers, P., Sousa Ribeiro, K. C., \& Sousa, A. F. (2005). Comparações múltiplas das carteiras de bolsa no Brasil: Avaliação da performance do índice de governança corporativa. REGE - Revista de Gestão, 12 (4), 55-72. doi:10.57 00/issn.2177-8736.rege.2005.36533

Rogers, P., Sousa Ribeiro, K. C., \& Sousa, A. F. (2007). Impactos de fatores macroeconômicos nas melhores práticas de governança corporativa no Brasil. Revista de Administração, 42 (3), 265-279. 
Sharpe, W. F. (1964). Capital asset prices: A theory of market equilibrium under conditions of risk. The Journal of Finance, 19(3), 425-442. doi:10.11 11/j.1540-6261.1964.tb02865.x

Shleifer, A., \& Vishny, R. W. (1986). Large shareholders and corporate control. Journal of Political Economy, 94(3, Part 1), 461-488. doi:10.1086/ 261385

Shleifer, A., \& Vishny, R. W. (1997). A survey of corporate governance. [Paper n. 1741], Harvard Institute of Economic Research, Harvard University, Cambridge, MA. doi:10.1111/j.1540-6261.1997.tb04820.x.

Silva, F. F., Azevedo, Y. G. P., Fonsêca, E. H. A., \& Gomes, A. M. (2019). Atributos de governança corporativa determinantes do disclosure de capital intelectual em empresas brasileiras. RGC - Revista de Governança Corporativa, 5(2), 75-105. doi:10.21434/rgc.v5i2.65

Silveira, A. M., Barros, L. B. C., \& Famá, R. (2003). Estrutura de governança e valor das companhias abertas brasileiras. Revista de Administração de Empresas, 43(3), 50-64. doi:10.1590/S0034-75902003000300005.

Terra, P. R. S., \& Lima, J. B. (2006). Governança corporativa e a reação do mercado de capitais à divulgação das informações contábeis. Revista Contabilidade E Finanças, 17(42), 35-49. doi:10.1590/S1519-70772006000 300004

Vieira, K. M., Velasquez, M. D., Losekann, V. L., \& Ceretta, P. S. (2011). A influência da governança corporativa no desempenho e na estrutura de capital das empresas listadas na Bovespa. Revista Universo Contábil, 7(1), 46-67. doi:10.4270/ruc.20117

Vieira, S. P., \& Mendes, A. G. S. T. (2006). Governança corporativa: Uma análise de sua evolução e impactos no mercado de capitais brasileiro. Revista Organizações em Contexto-online, 23, 48-67. doi:10.15603/1982-8756/roc. v2n3p48-67

Wernke, R., \& Lembeck, M. (2004). Análise de rentabilidade dos segmentos de mercado de empresa distribuidora de mercadorias. Revista Contabilidade $\mathcal{E}$ Finanças, 15(35), 68-83. doi:10.1590/S1519-70772004000200006

$\mathrm{Xu}, \mathrm{X} .$, \& Wang, Y. (1999). Ownership structure and corporate governance in Chinese stock companies. China Economic Review, 10 (1), 75-98. doi:10.10 16/S1043-951X(99)00006-1 


\section{J wropen orts}

Alyne C. S. Ganz, master by the Department of Social Sciences, Regional University of Blumenau (Furb); Josiane O. Schlotefeldt, master by the Department of Social Sciences, Regional University of Blumenau (Furb); Moacir M. Rodrigues Junior, doctor by the Graduate Program in Numerical Methods in Engineering, Federal University of Paraná (UFPR).

Alyne C. S. Ganz is now a doctoral student at the Graduate Program in Numerical Methods in Engineering of Federal University of Paraná (UFPR); Josiane O. Schlotefeldt is now professor of Accounting Sciences course at Centro Universitário - Católica de Santa Catarina (CatólicaSC); Moacir M. Rodrigues Junior is now professor at the Department of Mathematics and the Graduate Program in Accounting Sciences of Regional University of Blumenau (Furb).

Correspondence concerning this article should be addressed to Alyne C. S. Ganz, Avenida Coronel Francisco Heráclito dos Santos, 210, Jardim das Américas, Curitiba, Paraná, Brazil, CEP 81531-980.

E-mail: alyneserpa@hotmail.com

\section{EDITORIAL BOARD}

Editors-in-chief

Janette Brunstein

Silvia Marcia Russi De Domênico

Associated Editor

Flavio Luiz de Moraes Barboza

Technical Support

Vitória Batista Santos Silva

\section{EDITORIAL PRODUCTION}

Publishing Coordination

Jéssica Dametta

\section{Editorial Intern}

Paula Di Sessa Vavlis

Language Editor

Daniel de Almeida Leão

\author{
Layout Designer \\ Emap
}

Graphic Designer

Libro 